\title{
Pancreatic intraepithelial neoplasia and ductal adenocarcinoma induced by DMBA in mice. Effects of alcohol and caffeine ${ }^{1}$
}

\author{
Neoplasia pancreática intraepithelial e adenocarcinoma ductal induzidos pelo DMBA \\ em camundongos. Efeitos do álcool e da cafeína
}

\author{
Luiz Roberto Wendt ${ }^{2}$, Alessandro Bersch Osvaldt ${ }^{2}$, Vivian Pierre Bersch ${ }^{3}$, Rita de Cássia Schumacher ${ }^{3}$, Maria \\ Isabel Albano Edelweiss ${ }^{4}$, Luiz Rohde ${ }^{5}$ \\ 1. Research performed at Experimental Division of Research Center and Pathology Service of Hospital de Clinicas de Porto Alegre, Medical School, \\ Rio Grande do Sul Federal University (UFRGS). Porto Alegre, Brazil. \\ 2. Master and PhD in Surgery Post-Graduation Program of UFRGS. Brazil. \\ 3. Master in Surgery Post-Graduation Program of UFRGS. Brazil. \\ 4. PhD, Full Professor, Division of Pathology of UFRGS. Brazil. \\ 5. PhD, Full Professor of Surgery of UFRGS. Chief of Digestive Surgery of Hospital de Clinicas de Porto Alegre. Brazil.
}

\begin{abstract}
Purpose: To evaluate the effects of alcohol and caffeine in a pancreatic carcinogenesis mouse model induced by 7,12dimethylbenzantracene (DMBA), according to the PanIN classification system. Methods: 120 male, Mus musculus, CF1 mice were divided into four groups. Animals received either water or caffeine or alcohol or alcohol + caffeine in their drinking water. In all animals, $1 \mathrm{mg}$ of DMBA was implanted into the head of the pancreas. After 30 days, euthanasia was performed; excised pancreata were then fixed in formalin, stained with hematoxylin-eosin and categorized as follows: normal ducts, reactive hyperplasia, PanIN-1A, PanIN-1B, PanIN-2, PanIN-3 or adenocarcinoma. Results: PanIN lesions were verified in all groups. Adenocarcinoma was detected in 15\% of animals in the caffeine group, $16.6 \%$ in the water group, $23.8 \%$ in the alcohol + caffeine group and 52.9\% in the alcohol group $(P<0.05)$. Conclusions: The experimental pancreatic carcinogenesis mouse model using DMBA effectively induces PanIN lesions and pancreatic adenocarcinoma. This study verified the association between alcohol use and pancreatic adenocarcinoma; caffeine did not present the same effect
\end{abstract}

Key words: Caffeine. 9,10-Dimethyl-1,2-benzanthracene. Adenocarcinoma. Pancreas. Mice.

\section{RESUMO}

Objetivo: Avaliar os efeitos do álcool e da cafeína na carcinogênese pancreática induzida pelo 7,12-dimetilbenzantraceno (DMBA) em camundongos, descrevendo as lesões de acordo com a classificação das neoplasias pacreáticas intraepiteliais (PanIN). Métodos: 120 camundogos machos, Mus musculus, CF-1 foram divididos em quatro grupos. Animais receberam água ou cafeína ou álcool ou álcool + cafeína para beber. Em todos animais, 1 mg de DMBA foi implantado na cabeça do pâncreas. Após 30 dias, eutanásia foi realizada, o pâncreas foi removido, fixado em formalina e corado com hematoxilina e eosina sendo classificado em: ductos normais, hiperplasia reativa, PanIN-1A, PanIN-1B, PanIN-2, PanIN-3 ou adenocarcinoma. Resultados: Neoplasias pancreáticas intraepiteliais foram encontradas em todos grupos. Adenocarcinoma foi detectado em 15\% dos animais do grupo cafeína, 16,6\% do grupo água, 23,8\% do grupo álcool + cafeína e 52,9\% do grupo álcool $(\mathrm{P}<0,05)$. Conclusões: O modelo experimental de carcinogênese pancreática em camundongos utilizando DMBA induz neoplasias pancreáticas intraepiteliais (PanIN) e adenocarcinoma pancreático. Este estudoverificou associação entre álcool e adenocarcinoma pancreático, enquanto a cafeína não demonstrou este efeito. Descritores: Cafeína. 9,10-Dimetil-1,2-benzantraceno. Adenocarcinoma. Pâncreas. Camundongos. 


\section{Introduction}

The 5-year survival rate of pancreatic ductal adenocarcinoma (PDA) is below 5\% $\%^{1 ; 2}$. The incurability of this "dismal disease" is reflected in identical annual incidence and mortality figures ${ }^{3}$. Approximately $80 \%$ of patients present unresectable disease when they are diagnosed ${ }^{2}$. Therefore, for most patients, only a palliative treatment is offered. These data highlight the importance of the diagnosis of early pancreatic lesions and the identification of possible PDA promoters. Although the identification and treatment of pre-invasive pancreatic ductal lesions may potentially prevent PDA, the study of these precursor lesions in the pancreas has been impaired due to the lack of internationally accepted nomenclature and diagnosis criteria ${ }^{4}$. Recent studies have characterized pancreatic intraepithelial lesions (PanIN), thereby unifying the nomenclature and proposing a morphological progression model for PDA ${ }^{4-7}$ as well as correlating these early lesions with specific molecular genetic alterations ${ }^{6 ; 8}$. Animal models for pancreatic cancer should mimic all aspects of human disease ${ }^{9}$. Chemical agents ( $N$-nitroso-bis(2-oxopropyl) amine and 7,12-dimethylbenzanthracene) and transgenic mice (PDX-1-Cre;LSL-KRAS ${ }^{\mathrm{G} 12 \mathrm{D}}$ and P48 ${ }^{+/ \mathrm{Cre}}$;LSLKRAS $^{\mathrm{G} 12 \mathrm{D}}$ ) are the pancreatic carcinogenesis models more used. Pancreatic implantation of 7,12dimethylbenzanthracene (DMBA) have previously been reported ${ }^{10-15}$ and produces a phenotype of ductal adenocarcinoma with mutated K-ras ${ }^{11 ; 16}$. Zehnder et al. first described the induction of PDA in mice using DMBA, reducing the time of neoplasia induction to only 2 months ${ }^{14}$. Osvaldt et al. related the development of PanIN and ductal adenocarcinoma in a DMBA-induced model in mice ${ }^{15}$. The aim of the this study was to evaluate the effects of alcohol and caffeine in a DMBA-induced pancreatic carcinogenesis mouse model according to the PanIN classification system.

\section{Methods}

\section{Animal model}

Animal care are provided according to the Guide for the Care and Use of Laboratory Animals ${ }^{17}$. A total of 120 Mus musculus strain CF1 male adult mice, kept in a luminosity circadian cycle with environmental temperature control $\left(18-23^{\circ} \mathrm{C}\right)$ and relative humidity control (40-70\%), were divided into four groups. These groups received solutions in the pre- and post-operative periods for 30 days according to their group (Table 1). The animals were anesthetized with $0.04 \mathrm{mg} / \mathrm{kg}$ subcutaneous atropine as a premedication, followed 10 min later by ketamine $(50 \mathrm{mg} / \mathrm{kg}$ ) and xylazine $(20 \mathrm{mg} / \mathrm{kg})$ intraperitoneally. Mice were submitted to pre-operative fasting for 6h. Median laparotomy and dissection of the pancreas via delicate release of the stomach and transversal colon was performed. Purse-string sutures of $5 \mathrm{~mm}$ in diameter, using 7-0 polypropylene threads, were performed at the head of the pancreas. Obstruction of the biliopancreatic duct had to be avoided. In addition, implantation of $1 \mathrm{mg}$ of DMBA crystals (Sigma, lot 21K3688, St. Louis, MO) was performed, with the aid of an previously calibrated infusion cannula. The simultaneous closing of the purse-string suture around the introductory device was performed according to a previously described technique ${ }^{15}$.The site of implantation was checked to ensure that spillage of DMBA did not occur.

TABLE 1 - Characterization of the experimental groups

\begin{tabular}{llll}
\hline Group & Pancreas & Pre-operative1 & Post-operative1 \\
\hline Water & DMBA & Water & Water \\
Alcohol & DMBA & Alcohol & Alcohol \\
Caffeine & DMBA & Caffeine & Caffeine \\
Alcohol + & DMBA & Alcohol + & Alcohol + \\
caffeine & & caffeine & caffeine \\
\hline
\end{tabular}

${ }^{1}$ Pre- and post-operative periods each of 30 days' duration

\section{Solutions}

a) Caffeine: 1,3,7-trimethylxanthine pure anhydrous caffeine (Caffeine, lot 110K0264; SigmaAldrich, Saint Louis, MO) was dissolved in water at room temperature at a rate of $40 \mathrm{mg} / 1000 \mathrm{ml}$ of water.

b) Alcohol: Cereal alcohol 96 GL was diluted in water at room temperature and a concentration of $6 \%$ alcohol/volume was used.
The consumption of drinking solutions offered to the animals was recorded daily and then the average consumption for each animal was calculated.

\section{Histological analysis}

Thirty days after the procedure and use of the respective solutions according to the assigned group, euthanasia was performed in a carbonic gas chamber (using $\mathrm{CO}_{2}$ ). The pancreata were excised, fixed in $10 \%$ 
buffered formalin, embedded in paraffin and stained with hematoxylin and eosin. The histological analysis was performed by two pathologists in a blinded fashion and categorized as follows. They assessed the pancreata by means of the PanIN classification system ${ }^{5}$. Normal ductal and ductular epithelium is a cuboidal to lowcolumnar epithelium with amphophilic cytoplasm. Reactive hyperplasia was defined as an increase in the number of epithelial cells alongside the DMBA implantation pouch. PanIN-1A are flat epithelial lesions composed of tall columnar cells with basally located nuclei and abundant supranuclear mucin. The nuclei are small, and round to oval in shape. When oval, the nuclei are oriented perpendicular to the basement membrane. PanIN-1B are epithelial lesions that have a papillary, micropapillary or basally pseudostratified architecture, but are otherwise identical to PanIN-1A. PanIN-2 are mucinous epithelial lesions that may be flat but are mostly papillary. Cytologically, by definition, these lesions must have some nuclear abnormalities. These abnormalities may include some loss of polarity, nuclear crowding, enlarged nuclei, pseudo-stratification and hypercromatism. These nuclear abnormalities fall short of those seen in PanIN-3. Mitoses are rare, but when present are non-luminal (not apical) and are not atypical. PanIN-3 lesions are usually papillary or micropapillary; however, they may rarely be flat. True cribriforming, the "budding off" of small clusters of epithelial cells into the lumen, and luminal necrosis, should all suggest the diagnosis of PanIN-3. Cytologically, these lesions are characterized by a loss of nuclear polarity, dystrophic goblet cells (goblet cells with nuclei oriented towards the lumen and mucinous cytoplasm oriented towards the basement membrane), mitoses that may occasionally be abnormal, nuclear irregularities and prominent (macro) nucleoli. The lesions resemble carcinoma at the cytonuclear level, but invasion through the basement membrane is absent. Invasive adenocarcinoma was diagnosed in the presence of infiltrating irregular neoplastic glands within a desmoplastic stroma ${ }^{18}$. The presence of more than one alteration in the same case has always been considered to be at the most advanced stage.

\section{Ethics}

Experiments were approved by the Ethical Committee of Hospital de Clinicas de Porto Alegre.

\section{Statistical analysis}

The Pearson chi-squared test and the Fisher exact test were used to evaluate the statistical significance of differences between comparisons. The significance level was defined at $P<0,05$.

\section{Results}

This pancreatic carcinogenesis model used 120 mice, distributed into four groups of 30 animals. Of these, 33 (27.5\%) died in the post-operative period, and were therefore excluded from the study. Of the remaining 87 animals, 5 (5.7\%) were also excluded because histological analysis was impaired by the autolysis of the material examined. Therefore, a total of 38 animals were lost (31.6\%). In the DMBA + water group, 6 animals were lost (20\%); in the DMBA + alcohol group, 13 animals were lost (43.3\%); in the DMBA + caffeine group, 10 animals were lost (33.3\%), and in the DMBA + alcohol + caffeine group, 9 animals were lost (30\%). No statistical differences in relation to the losses between groups were observed ( $P=0.2780$, Chi-squared test).

\section{Consumption of solutions}

The consumption of drinking solutions offered to the animals was similar in all groups (Table 2).

TABLE 2 - Average solution volume (ml) daily ingested per mouse from the different groups

\begin{tabular}{lcc}
\hline Group & Pre-operative & Post-operative \\
\hline Water + DMBA & 8.02 & 6.80 \\
Alcohol + DMBA & 8.90 & 9.10 \\
Caffeine + DMBA & 9.88 & 9.30 \\
Alcohol + caffeine + DMBA & 9.50 & 9.28 \\
\hline
\end{tabular}

\section{Histological analysis}

The histological findings ranged from normal ducts, reactive hyperplasia and all PanIN-type alterations (Figure 1), to invasive adenocarcinoma (Figure 2). The frequency of the histological diagnoses in the different groups is summarized in Table 3. Statistical analysis of these histological data showed that the alcohol group had a significantly greater incidence of invasive adenocarcinoma $(P<0.05)$ than the water group (control group) or the caffeine group. No statistical differences were observed when the other groups were compared. 


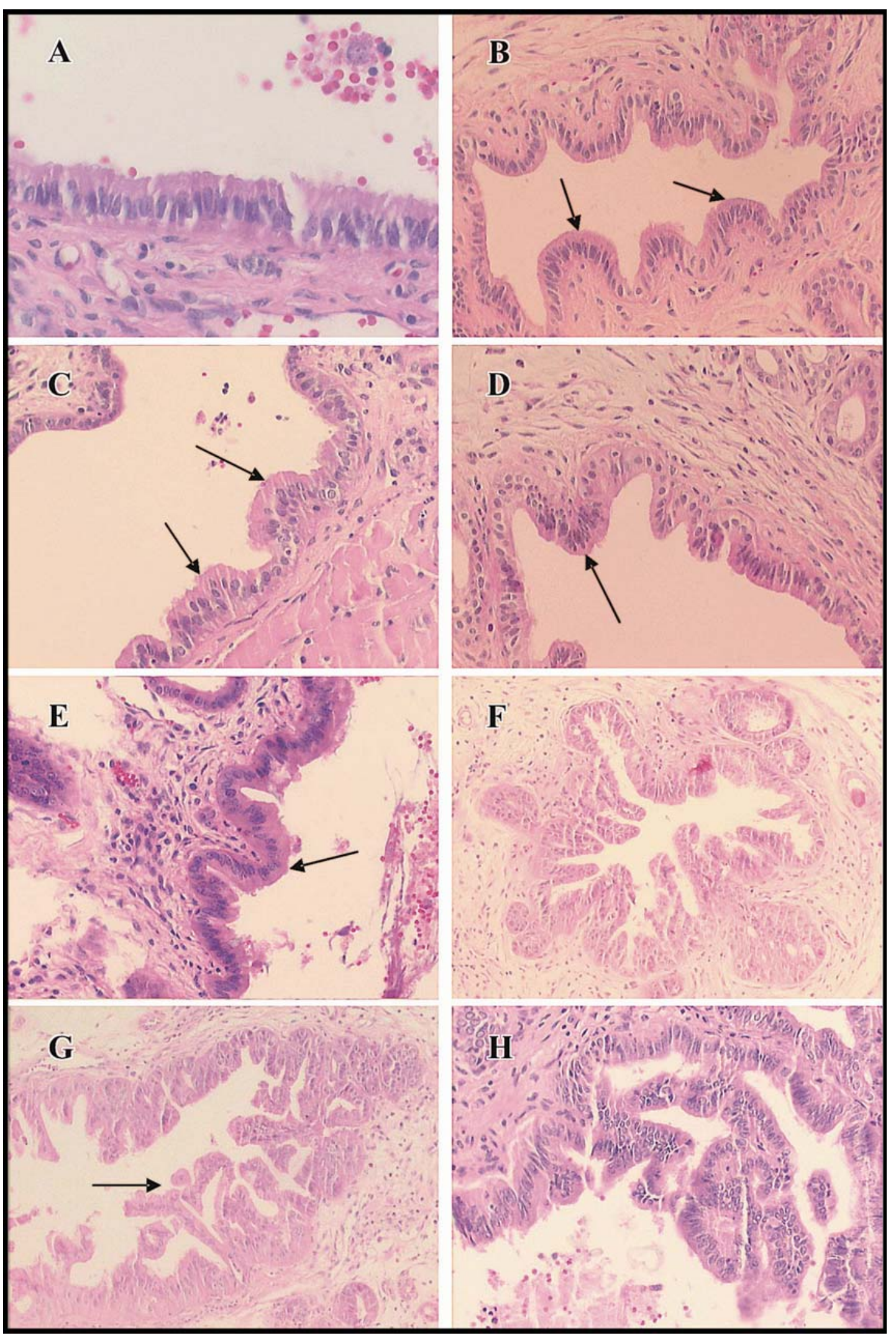

FIGURE 1 - Precursor lesions classified as PanIN: A) PanIN-1A with cylindrical epithelium, magnification of $\times 40$ from the original; B) PanIN-1B with papillary projections (arrows), magnification of $\times 20$ from the original; C) PanIN-1B with papillary projections (arrows), magnification of $\times 10$ from the original; D) PanIN-2 with papillary projections with nucleuses at different heights (arrow), magnification of $\times 20$ from the original; E) PanIN-2 with papillary projections (arrows), magnification of $\times 20$ in the original; F) PanIN-3, magnification of $\times 10$ from the original; G) PanIN-3 with decapitation (arrow), magnification of $\times 10$ from the original; $\mathrm{H}$ ) PanIN-3 with cribiform feature, magnification of $\times 20$ from the original. Slides stained using the hematoxylin and eosin technique 


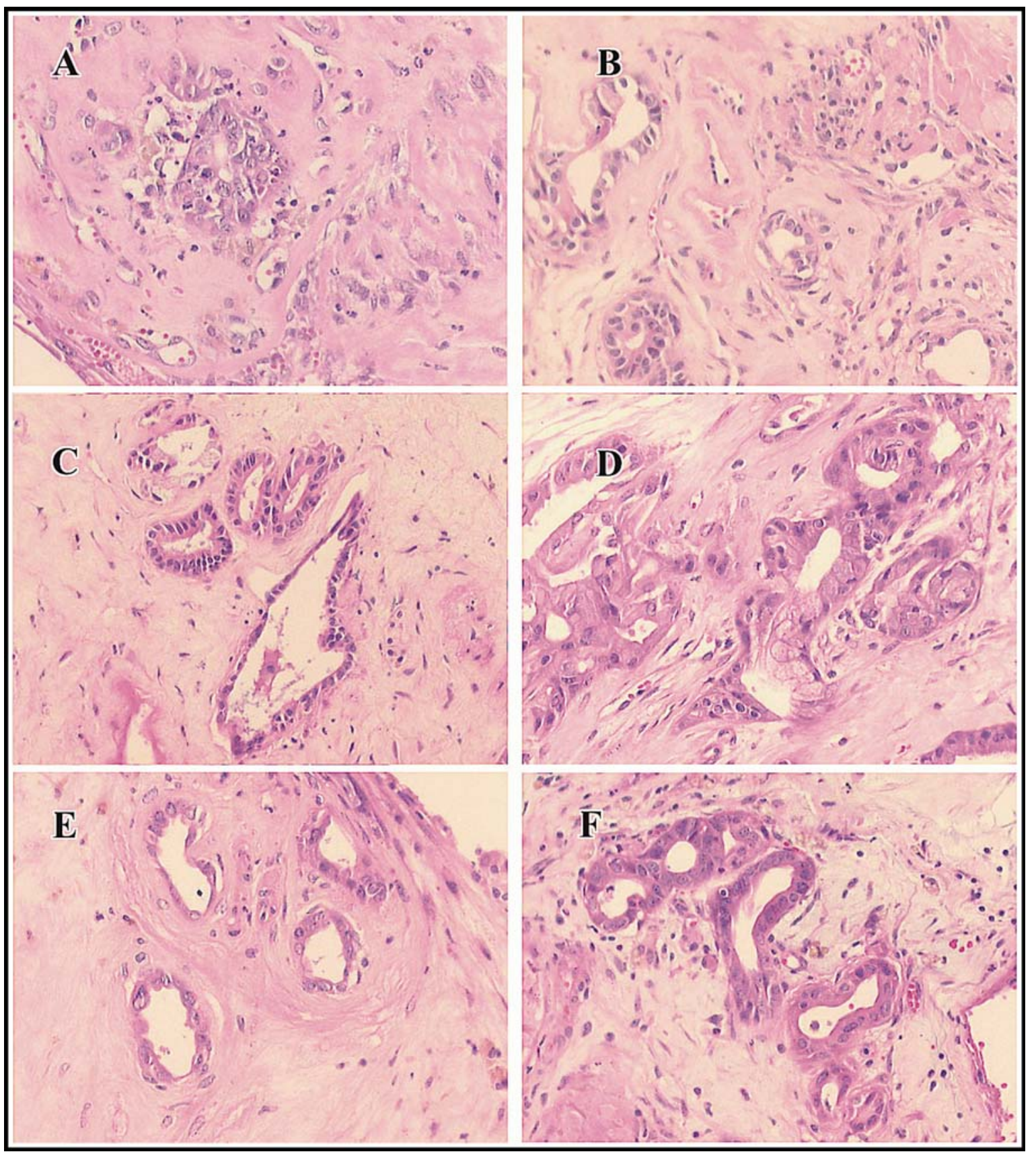

FIGURE 2 - Histological sections pointing out invasive pancreas adenocarcinoma. A)Animal from alcohol group, magnification of $\times 20$ from the original; B) Animal from alcohol + caffeine group, magnification of $\times 20$ from the original; C) Desmoplasic stroma with atypical glands, magnification of $\times 20$ from the original; D) Animal from alcohol group, magnification of $\times 20$ from the original; E) and F) Desmoplasic stroma with atypical glands, magnification of $\times 20$ from the original. Slides stained using the hematoxylin and eosin technique

TABLE 3 - Frequency of histological diagnoses in the different groups

\begin{tabular}{lllllllll}
\hline & \multicolumn{1}{c}{} & \multicolumn{2}{c}{ Reactive } & \multicolumn{2}{c}{ PanIN } & \multicolumn{2}{c}{ Invasive } \\
& $n$ & Normal & hyperplasia & Ia & Ib & II & III & carcinoma \\
\hline DMBA + water & 24 & 0 & 4 & 1 & 4 & 8 & 3 & $4(16.6 \%)$ \\
DMBA + alcohol & 17 & 1 & 1 & 0 & 1 & 3 & 2 & $9(52.9 \%) \mathbf{a}$ \\
DMBA + caffeine & 20 & 3 & 1 & 1 & 4 & 4 & 4 & $3(15 \%)$ \\
$\begin{array}{l}\text { DMBA + alcohol + } \\
\text { caffeine }\end{array}$ & 21 & 1 & 0 & 1 & 2 & 10 & 2 & $5(23.8 \%)$ \\
\hline
\end{tabular}

$P<0.05$ (Fisher exact Test) 


\section{Discussion}

The experimental model adopted in the present study allowed the induction of pancreatic carcinogenesis through the implantation of DMBA in the pancreas, as previously described by Dissin et al. ${ }^{10}$, Rivera et al. ${ }^{11}$ and Bockman et al. ${ }^{12}$. The animal selected for the experimental studies mentioned above was the rat, with the observation period ranging from 4 to 12 months for pancreatic carcinogenesis induction. In our study, the animal selected for experimental use was the mouse, as described by Zehnder et al. ${ }^{14}$ and Osvaldt et al. ${ }^{15}$, and a reduced time period was needed for pancreatic carcinogenesis induction. The model adopted was satisfactory because the development of precursor lesions (PanINs), as well as of invasive adenocarcinoma, was observed in all groups studied. The total number of losses was 38 (31.6\%) and no statistical differences in the comparison between groups were observed. This loss rate is comparable to the loss rates found in other studies involving DMBA ${ }^{15 ; 16}$. In its histological analysis, this study used the PanIN classification system originally proposed by Klimstra and Longnecker in $1994{ }^{19}$. The original PanIN definitions used were officially published in $2001{ }^{5}$. Previous studies used the same experimental model but did not adopt this classification system to describe pre-invasive lesions ${ }^{10-14 ; 16 ; 20}$. A recent study described the PanIN lesions in transgenic mice ${ }^{21}$. PanINs are defined as epithelial neoplasic proliferations in smallcaliber pancreatic ducts ${ }^{22}$ and may be divided into three groups. The diagnostic criteria for each PanIN group were described before. Invasive adenocarcinomas generally demonstrate the following, which are considered the main histological characteristics distinguishing them from PanINs: a) incomplete glands; b) variation in nuclear size of $>4: 1$ in a single duct; c) intraluminal necrosis; d) perineural and vascular invasion; e) glands next to muscular vessels; and f) a haphazard growth pattern ${ }^{22}$. The identification of possible promotive or protective PDA factors is another endpoint under study. The use of tobacco is an identified risk factor and it is estimated that tobacco is responsible for up to $30 \%$ of the pancreatic tumors that occur and that the risk remains increased for a period of 10-15 years after smoking cessation ${ }^{23-26}$. Caffeine has been widely studied as an agent that induces different types of neoplasia. Cohort epidemiological studies have demonstrated no association between caffeine and cancer in any type of organ ${ }^{27}$. A case-case study has demonstrated that the activation of the K-ras oncogene is more frequent in patients with pancreatic cancer who make regular use of coffee compared with those who do not; therefore, caffeine could modulate the activation of the K-ras oncogene ${ }^{28}$. On the other hand, most epidemiological studies do not demonstrate an association between the consumption of caffeine and pancreatic cancer ${ }^{29-32}$. Our study also did not show an association between caffeine and pancreatic cancer, as the relative frequency of invasive adenocarcinoma in the caffeine group (15\%) was similar to that of the water group (16.6\%). When the alcohol group and the alcohol + caffeine group were compared, a reduction in the adenocarcinoma frequency in the alcohol + caffeine group without reaching statistical significance was observed, which could demonstrate the possible protective effect of caffeine in this experimental model. The association between the consumption of alcohol and pancreatic cancer has been widely researched. Epidemiological studies on the consumption of alcohol and the risk of cancer in humans confirm the increased risk of mouth, pharyngeal, laryngeal, esophagus and liver cancer in alcoholics ${ }^{33 ; 34}$. Studies have demonstrated the association between the consumption of alcohol and pancreatic cancer ${ }^{29 ; 35}$, although the vast majority of epidemiological studies do not confirm this association $31 ; 32 ; 36$. There is only indirect epidemiological evidence of this association, as the consumption of alcohol increases the risk of pancreatitis ${ }^{37}$ and pancreatitis increases the risk of pancreatic cancer ${ }^{38}$. In the present study, a higher relative frequency of invasive adenocarcinoma was found in the alcohol group $(\mathrm{P}<0.05$; Fisher exact test), demonstrating an association between alcohol and pancreatic cancer in this experimental model. This association could be partly explained by the following reason: alcohol causes pancreatitis (tissue inflammation) and the concomitant presence of DMBA and an accelerated process of cell division causes DNArepair mechanisms to be overloaded ${ }^{15}$. In humans, this occurs in a similar way. Exposure to DMBA and others polycyclic aromatic hydrocarbons occurs through the smoking of tobacco ${ }^{39}$. Pancreatic tissue with chronic inflammation (alcoholic pancreatitis) has an increased risk of cancer when it is exposed to tobacco smoke ${ }^{40}$. Loss of p16 expression occurs in high-grade PanINs arising in patients with chronic pancreatitis ${ }^{41}$.

\section{Conclusions}

This experimental model of pancreatic carcinogenesis using DMBA in mice is effective for the induction of the PanIN lesions and invasive pancreatic adenocarcinoma. The adoption of this systematized classification to identify and characterize pre-invasive lesions allows the comparison of results between researchers. In this study, the association between alcohol and pancreatic cancer was observed, but caffeine did not demonstrate this effect. 


\section{References}

1. DiMagno EP, Reber HA, Tempero MA. AGA technical review on the epidemiology, diagnosis, and treatment of pancreatic ductal adenocarcinoma. American Gastroenterological Association. Gastroenterology. 1999; 117(6):1464-84.

2. Yeo TP, Hruban RH, Leach SD, Wilentz RE, Sohn TA, Kern SE, Iacobuzio-Donahue CA, Maitra A, Goggins M, Canto MI, Abrams RA, Laheru D, Jaffee EM, Hidalgo M, Yeo CJ. Pancreatic cancer. Curr Probl Cancer. 2002; 26(4):176-275.

3. Jemal A, Murray T, Samuels A, Ghafoor A, Ward E, Thun MJ. Cancer statistics, 2003. Cancer J Clin. 2003; 53(1):5-26.

4. Hruban RH, Takaori K, Klimstra DS, Adsay NV, Albores-Saavedra J, Biankin AV, Biankin SA, Compton C, Fukushima N, Furukawa T, Goggins M, Kato Y, Kloppel G, Longnecker DS, Luttges J, Maitra A, Offerhaus GJ, Shimizu M, Yonezawa S. An illustrated consensus on the classification of pancreatic intraepithelial neoplasia and intraductal papillary mucinous neoplasms. Am J Surg Pathol. 2004; 28(8):977-87.

5. Hruban RH, Adsay NV, Albores-Saavedra J, Compton C, Garrett ES, Goodman SN, Kern SE, Klimstra DS, Kloppel G, Longnecker DS, Luttges J, Offerhaus GJ. Pancreatic intraepithelial neoplasia: a new nomenclature and classification system for pancreatic duct lesions. Am J Surg Pathol. 2001; 25(5):579-86.

6. Maitra A, Adsay NV, Argani P, Iacobuzio-Donahue C, De Marzo A, Cameron JL, Yeo CJ, Hruban RH. Multicomponent analysis of the pancreatic adenocarcinoma progression model using a pancreatic intraepithelial neoplasia tissue microarray. Mod Pathol. 2003; 16(9):902-12.

7. Takaori K, Hruban RH, Maitra A, Tanigawa N. Pancreatic intraepithelial neoplasia. Pancreas. 2004; 28(3):257-62.

8. Hruban RH, Iacobuzio-Donahue C, Wilentz RE, Goggins M, Kern SE. Molecular pathology of pancreatic cancer. Cancer J. 2001; 7(4):251-8.

9. Hotz HG, Hines OJ, Foitzik T, Reber HA. Animal models of exocrine pancreatic cancer. Int J Colorectal Dis. 2000; 15(3):136-43.

10. Dissin J, Mills LR, Mains DL, Black O, Jr., Webster PD, III. Experimental induction of pancreatic adenocarcinoma in rats. J Natl Cancer Inst. 1975; 55(4):857-64.

11. Rivera JA, Graeme-Cook F, Werner J, Z’graggen K, Rustgi AK, Rattner DW, Warshaw AL, Fernandez-Del Castillo C. A rat model of pancreatic ductal adenocarcinoma: targeting chemical carcinogens. Surgery. 1997; 122(1):82-90.
12. Bockman DE, Black O, Jr., Mills LR, Mainz DL, Webster PD, III. Fine structure of pancreatic adenocarcinoma induced in rats by 7,12 dimethylbenz(a)anthracene. J Natl Cancer Inst. 1976; 57(4):931-6.

13. Jimenez RE, Z'graggen K, Hartwig W, Graeme-Cook F, Warshaw AL, Fernandez-Del Castillo C. Immunohistochemical characterization of pancreatic tumors induced by dimethylbenzanthracene in rats. Am J Pathol. 1999; 154(4):1223-9.

14. Zehnder P, Z'Graggen K, Ozawa F, Mazzucchelli L, Büchler MW. First description of a carcinogen induced mouse model of ductal pancreatic adenocarcinoma: dimethylbenzanthraceno induces ductal adenocaarcinoma of the pancreas in a dysplasiacarcinoma type sequence. HPB Surg. 2000; 2(2):124.

15. Osvaldt AB, Wendt LR, Backes AN, Schumacher RC, Bersch VP, Edelweiss MIA, Rohde L. Pancreatic intraepithelial neoplasia and ductal adenocarcinoma induced by DMBA in mice. Surgery. 2006;140:803-9.

16. Z’graggen K, Warshaw AL, Werner J, Graeme-Cook F, Jimenez RE, Fernandez-Del Castillo C. Promoting effect of a high-fat/high-protein diet in DMBA-induced ductal pancreatic cancer in rats. Ann Surg. 2001; 233(5):68895.

17. Commission on Life Sciences National Research Council. Guide for care and use of laboratory animals. 7ed. Washington DC: National Academy Press; 1996.

18. Kloppel G, Luttges J. WHO-classification 2000: exocrine pancreatic tumors. Verh Dtsch Ges Pathol. 2001; 85:219-28.

19. Klimstra DS, Longnecker DS. K-ras mutations in pancreatic ductal proliferative lesions. Am J Pathol. 1994; 145(6):1547-50.

20. Bockman DE, Guo J, Buchler P, Muller MW, Bergmann F, Friess H. Origin and development of the precursor lesions in experimental pancreatic cancer in rats. Lab Invest. 2003; 83(6):853-9.

21. Hingorani SR, Petricoin EF, Maitra A, Rajapakse V, King C, Jacobetz MA, Ross S, Conrads TP, Veenstra TD, Hitt BA, Kawaguchi Y, Johann D, Liotta LA, Crawford HC, Putt ME, Jacks T, Wright CV, Hruban RH, Lowy AM, Tuveson DA. Preinvasive and invasive ductal pancreatic cancer and its early detection in the mouse. Cancer Cell. 2003; 4(6):437-50.

22. Maitra A, Fukushima N, Takaori K, Hruban RH. Precursors to invasive pancreatic cancer. Adv Anat Pathol. 2005; 12(2):81-91.

23. Li D, Xie K, Wolff R, Abbruzzese JL. Pancreatic cancer. Lancet. 2004; 363(9414):1049-57.

24. Boyle P, Maisonneuve P, Bueno dM, Ghadirian P, Howe GR, Zatonski W, Baghurst P, Moerman CJ, Simard A, Miller AB, Przewoniak K, McMichael AJ, Hsieh CC, Walker AM. Cigarette smoking and pancreas cancer: a 
case control study of the search programme of the IARC. Int J Cancer. 1996; 67(1):63-71.

25. Simon B, Printz H. Epidemiologic Trends in Pancreatic Neoplasias. Dig Dis. 2001; 19(1):6-14.

26. Lowenfels AB, Maisonneuve P. Environmental factors and risk of pancreatic cancer. Pancreatology. 2003; 3(1):1-7.

27. Martin JB, Annegers JF, Curb JD, Heyden S, Howson C, Lee ES, Lee M. Mortality patterns among hypertensives by reported level of caffeine consumption. Prev Med. 1988; 17(3):310-20.

28. Porta M, Malats N, Alguacil J, Ruiz L, Jariod M, Carrato A, Rifa J, Guarner L. Coffee, pancreatic cancer, and Kras mutations: updating the research agenda. J Epidemiol Community Health. 2000; 54(9):656-9.

29. Heuch I, Kvale G, Jacobsen BK, Bjelke E. Use of alcohol, tobacco and coffee, and risk of pancreatic cancer. Br J Cancer. 1983; 48(5):637-43.

30. Vineis P. ras Mutations and a cup of coffee: cause, confounder, effect modifier, or what else? J Epidemiol Community Health. 1999; 53(11):685.

31. Villeneuve PJ, Johnson KC, Hanley AJ, Mao Y. Alcohol, tobacco and coffee consumption and the risk of pancreatic cancer: results from the Canadian enhanced surveillance system case-control project. Canadian Cancer Registries Epidemiology Research Group. Eur J Cancer Prev. 2000; 9(1):49-58.

32. Michaud DS, Giovannucci E, Willett WC, Colditz GA, Fuchs CS. Coffee and alcohol consumption and the risk of pancreatic cancer in two prospective United States cohorts. Cancer Epidemiol Biomarkers Prev. 2001; 10(5):429-37.

33. Longnecker MP. Alcohol consumption and risk of cancer in humans: an overview. Alcohol. 1995; 12(2):87-96.

34. Longnecker MP, Enger SM. Epidemiologic data on alcoholic beverage consumption and risk of cancer. Clin Chim Acta. 1996; 246(1-2):121-41.
35. Ye W, Lagergren J, Weiderpass E, Nyren O, Adami HO, Ekbom A. Alcohol abuse and the risk of pancreatic cancer. Gut. 2002; 51(2):236-9.

36. Lin Y, Tamakoshi A, Kawamura T, Inaba Y, Kikuchi S, Motohashi Y, Kurosawa M, Ohno Y. Risk of pancreatic cancer in relation to alcohol drinking, coffee consumption and medical history: findings from the Japan collaborative cohort study for evaluation of cancer risk. Int J Cancer. 2002; 99(5):742-6.

37. Singh M, Simsek H. Ethanol and the pancreas. Current status. Gastroenterology. 1990; 98(4):1051-62.

38. Lowenfels AB, Maisonneuve P, Cavallini G, Ammann RW, Lankisch PG, Andersen JR, DiMagno EP, AndrenSandberg A, Domellof L. Pancreatitis and the risk of pancreatic cancer. International Pancreatitis Study Group. N Engl J Med. 1993; 328(20):1433-7.

39. International Agency for Research on Cancer. Certain polycyclic aromatic hydrocarbons and heterocyclic compounds. Available from : http://monographs.iarc.fr/

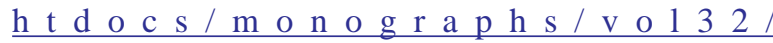
benz\%5Ba\%5Danthracene.html [Acessed July 2, 2004].

40. Li D, Jiao L. Molecular epidemiology of pancreatic cancer. Int J Gastrointest Cancer. 2003; 33(1):3-14.

41. Rosty C, Geradts J, Sato N, Wilentz RE, Roberts H, Sohn T, Cameron JL, Yeo CJ, Hruban RH, Goggins M. p16 Inactivation in pancreatic intraepithelial neoplasias (PanINs) arising in patients with chronic pancreatitis. Am J Surg Pathol. 2003; 27(12):1495-501.

\section{Acknowledgements}

Pathology Service and Experimental Division of Research Center of Hospital de Clinicas de Porto Alegre. Supported by grants from Research and Events Incentive Fund of Hospital de Clinicas de Porto Alegre (FIPE) and from National Council of Technological and Scientific Development (CNPq), Brazil. There are no financial or other relationships that might lead to a conflict of interest.

\section{Correspondence:}

Luiz Roberto Rigo Wendt

Rua Alvaro Nunes Pereira, 285/601

90570-110 Porto Alegre- RS Brazil

Phone / Fax: (55 51)3346-1178 / 3330-9700

lwendt@hcpa.ufrgs.br
Conflict of interest: none Financial source: none

Received: January 26, 2007

Review: February 23, 2007

Accepted: March 20, 2007

\section{How to cite this article}

Wendt LR, Osvaldt AB, Bersch VP, Schumacher RC, Edelweiss MIA, Rohde L. Pancreatic intraepithelial neoplasia and ductal adenocarcinoma induced by DMBA in mice: effects of alcohol and caffeine. Acta Cir Bras. [serial on the Internet] 2007 May-June;22(3). Available from URL: http://www.scielo.br/acb 